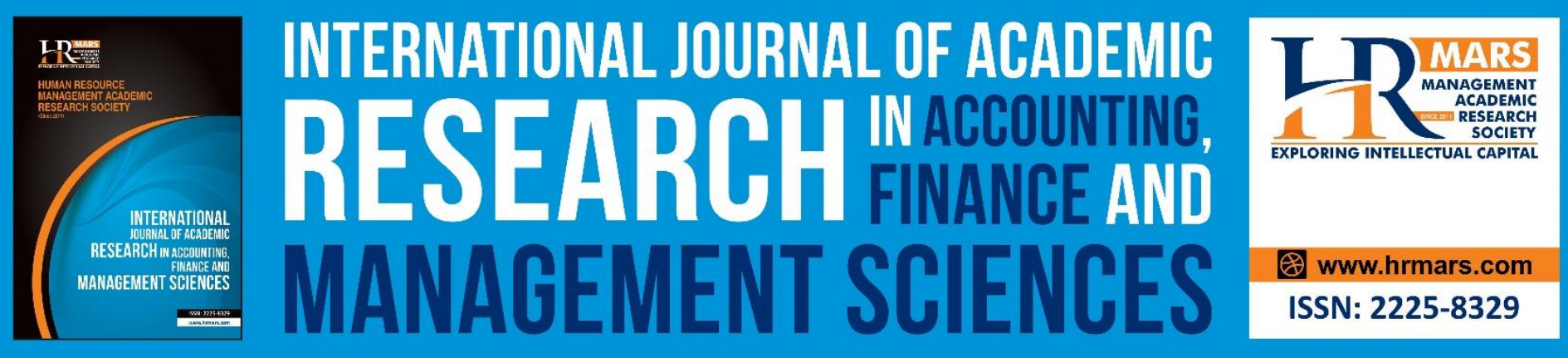

\title{
The Interaction Effect of Human Capital Efficiency on the Nexus between Intellectual Capital and Profitability: Evidence from Malaysian SMEs
}

\author{
Hapsah S. Mohammad
}

To Link this Article: http://dx.doi.org/10.6007/IJARAFMS/v11-i1/8995

DOI:10.6007/IJARAFMS /v11-i1/8995

Received: 15 January 2021, Revised: 18 February 2021, Accepted: 28 February 2021

Published Online: 20 March 2021

In-Text Citation: (Mohammad, 2021)

To Cite this Article: Mohammad, H. S. (2021). The Interaction Effect of Human Capital Efficiency on the Nexus between Intellectual Capital and Profitability: Evidence from Malaysian SMEs. International Journal of Academic Research in Accounting Finance and Management Sciences, 11(1), 183-200.

Copyright: (C) 2021 The Author(s)

Published by Human Resource Management Academic Research Society (www.hrmars.com)

This article is published under the Creative Commons Attribution (CC BY 4.0) license. Anyone may reproduce, distribute, translate and create derivative works of this article (for both commercial and non-commercial purposes), subject to full attribution to the original publication and authors. The full terms of this license may be seen

at: http://creativecommons.org/licences/by/4.0/legalcode

Vol. 11, No. 1, 2021, Pg. 183 - 200

http://hrmars.com/index.php/pages/detail/IJARAFMS

JOURNAL HOMEPAGE

Full Terms \& Conditions of access and use can be found at

http://hrmars.com/index.php/pages/detail/publication-ethics 


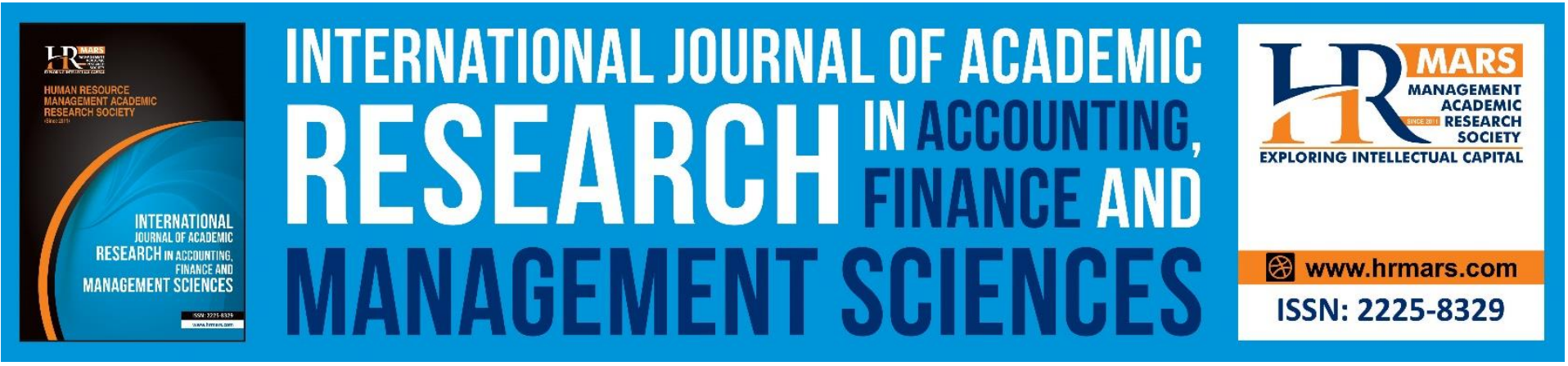

\title{
The Interaction Effect of Human Capital Efficiency on the Nexus between Intellectual Capital and Profitability: Evidence from Malaysian SMEs
}

\author{
Hapsah S. Mohammad \\ Faculty of Accountancy, Universiti Teknologi MARA (UiTM) Sabah Branch, Kota Kinabalu \\ Campus, Sabah, Malaysia \\ Email: hapsahsm@uitm.edu.my
}

\begin{abstract}
The purpose of this paper is to empirically investigate if intellectual capital has an impact on profitability while considering the interaction effect of human capital efficiency. The data are drawn from LEAP market of Bursa Malaysia over the three-year period of 2017 to 2019. Modified Value Added Intellectual Coefficient (MVAIC) method is applied to measure intellectual capital and return on asset (ROA) as a proxy for profitability. The empirical findings, after controlling for firm size and leverage, indicate that intellectual capital is positive and significantly associated with profitability. However, the results show a mixed relationship between MVAIC components and profitability. The findings reveal positive and significantly association between human capital efficiency (HCE), capital employed efficiency (CEE) and ROA. Structural capital efficiency (SCE) has significant but negative relationship with ROA. While, relational capital efficiency (RCE) is proven to be statistically insignificant with ROA. However, when HCE interact with SCE and RCE, the results show that HCE moderates positively the effect of SCE and RCE on ROA. This is among the few studies that explore an empirical relationship between intellectual capital and profitability in the context of Malaysian SMEs and making a novel contribution in considering an interaction variable. However, the study examines one country and one industry, therefore, limit the generalisation of findings.
\end{abstract}

Keywoods: Intellectual Capital, Profitability, Interaction Effect, Human Capital Efficiency.

\section{Introduction}

Stakeholders comprising shareholders, managers, employees, governments, suppliers, customers and even the general public are concerned with firms' performance. Firms' performance which includes profitability, productivity, earnings, growth and market value are essential in any economy (Latif, Malik and Aslam, 2012; Smriti and Das, 2018). With regard to this, performing firms means income to stakeholders which provides spillover effects and multiplier effects for individuals, households and the economy as a whole. While, through 
INTERNATIONAL JOURNAL OF ACADEMIC RESEARCH IN ACCOUNTING, FINANCE AND MANAGEMENT SCIENCES

Vol. 11, No. 1, 2021, E-ISSN: 2225-8329 @ 2021 HRMARS

corporate taxes, enabling the implementation of infrastructure projects and social welfare programs by the government. In addition, when firms are performing, they will attract more investments, therefore creating employment which in turn leads to poverty reduction (Ali, 2014).

In view of the importance of firms' performance towards economic growth, theory such as resource-based view has attempted to shed lights on the importance of resources in achieving this goal. The theory argues firms' resources are the main drive behind competitiveness and firm growth. These resources are broadly classified into physical capital (e.g. land, premises, plant and machinery) and intellectual capital (e.g. experience, information technology, and intellectual skills). However, for these resources to be strategic assets they must be valuable, rare, inimitable and non-substitutable (Barney, 1991). As economy grows and evolves, scholars argue only inimitable and non-substitutable resources will become a source of competitive advantage, a source in value creation and act as driver for firm growth which ultimately enhance firm performance and these two characteristics are abundantly available in intellectual capital (AlMusali and Ku Ismail, 2016; Ozkan, Cakan and Kayacan, 2017; Nawaz and Haniffa, 2017; Tran and Vo, 2018; Xu and Li, 2019; Saewarno and Tjahjadi, 2020).

Undoubtedly, businesses in any economy must thrive in today's dynamic, globalization, competitive and changing market setting. In line with this, under the proposed 2012-2020 SME Master Plan, Malaysian SMEs aspire in becoming a globally competitive engine of growth that improve the country's income and leads to community well-being. It represents the government's ambition to reach the high-income nation by 2020. In view of this, SMEs must focus on intellectual capital by allocating enough resources through human, organizational and relational growth to react rapidly to transition. Recognising the significance of SMEs, in 2017 Bursa Malaysia launched Leading Entrepreneur Accelerator Platform Market or LEAP market providing SMEs with a platform for access to the Malaysian capital markets. Consequently, providing an avenue and enabling the use of measurement models such as MVAIC model in exploring the relationship between intellectual capital and firm performance.

In the context of the knowledge-based economy, intellectual capital has become an important factor that can determine the success or failure of SMEs, hence affecting performance (Ngah and Ibrahim, 2009; Xu and Li, 2019). In addition, to the best of the researchers' knowledge, prior studies on the impact of intellectual capital on firm performance of Malaysian SMEs are drawn from perceptual measures based on primary data such as questionnaires, interviews, observations (e.g. Muda and Rahman, 2018; Shaari, Isa and Khalique, 2018; Zin and Ashari, 2020). No research has been done on the relationship between intellectual capital and firm performance of SMEs in Malaysia using secondary data. Further, SMEs do not usually evaluate and consider intellectual capital, and because SMEs have distinct traits from big firms (Xu and Li, 2019), empirical research is required. In addition, limited studies have captured the interaction effect of human capital on other components of intellectual capital, which can then be linked with firm performance to gauge efficiency. Thus, an intellectual capital study in SMEs seems both promising and necessary. 
This study focuses on listed SMEs due to several reasons. First, SMEs are considered to be the driving force of Malaysia's economic growth. This is evident as Malaysia's SMEs GDP recorded a strong growth for 2017 at 7.2 per cent as compared to 5.2 per cent recorded in 2016 . This performance exceeded Malaysia's GDP and non-SMEs which only stood at 5.9 per cent and 5.1 per cent respectively (SME Corp Malaysia, 2019). Furthermore, SMEs do not normally measure and recognise intellectual capital and since SMEs have different characteristics from large companies empirical analysis becomes necessary (Ngah and Ibrahim, 2009; Xu and Li, 2019). As such, a study of intellectual capital in SMEs appears to be both appealing and appropriate. Second, the data for this analysis is obtained from the annual reports of listed SMEs (secondary data). Therefore, measurement models such as MVAIC model can be employed to measure intellectual capital efficiency in order to assess firm's ability to create value. MVAIC model has several advantages. It is useful for company-to-company or business unit-to-business unit comparison and the analysis provides a more comprehensive and accurate results. In addition, the data is relatively easy to obtain because they are sourced from the publicly available annual reports of the firms. Furthermore, the data on listed SMEs is only available in recent years (20172019), thus provides a fruitful setting for intellectual capital assessment. Third, prior empirical findings reported a variation on the value creation capability of the components of intellectual capital and their effect on firm performance. Thus, to further strengthen the nexus between intellectual capital and firm performance, this study will investigate the moderating effect of human capital efficiency on other components of intellectual capital and how these interaction affect firm performance. Further, analysis involving moderating variables in the intellectual capital literature is still in its infancy, thus making a novel contribution (Tiwari, 2020). Therefore, based on the research issues and gaps as discussed, the study intends to address the following research questions:

1. How does intellectual capital influence the profitability of listed SMEs in Malaysia?

2. What is the effect of MVAIC components namely HCE, SCE, RCE and CEE on the profitability of listed SMEs in Malaysia?

3. To what extent does HCE moderates SCE, RCE, CEE and profitability of listed SMEs in Malaysia?

The research questions outlined above are useful as guideline to achieve the following research objectives:

To examine the impact of intellectual capital on firms' profitability listed SMEs in Malaysia using MVAIC model.

1. To investigate the separate effect of MVAIC components namely HCE, SCE, RCE and CEE on firms' profitability of listed SMEs in Malaysia.

2. To determine the moderating effect of HCE on SCE, RCE, CEE and profitability of listed SMEs in Malaysia.

The study addresses the gap in the literature by exploring the association between intellectual capital and firm performance of listed SMEs in Malaysia. The empirical findings may assist SMEs in the recognition of resources that contribute significantly towards firms' performance. Thus, it 
will guide SMEs in the proper allocation of firms' investments. In addition, the findings of the study may be useful to SMEs in the formulation and implementation of business strategies. In view of this, SMEs may consider placing different emphasis on the components of intellectual capital as the firms' value creation capability is reflected by the efficiency level of the components. Furthermore, the findings may provide insights for firm managers to effectively and efficiently manage intellectual capital and may have important implications for institutional investors when using intellectual capital efficiency to assess firms' ability to create value.

The paper is divided into several parts. Section 2 deals with the theory related to intellectual capital, literature review and formulation of the hypotheses. Section 3 discussess the data, variables and research methodology used. Section 4 and 5 present the findings of the empirical analysis and discussion of the results and concluded with limitation of the study and some recommendations for future research.

\section{Literature Review and Hypotheses Development \\ Resource-Based Theory}

Resource-based theory has been used extensively in explaining the relationship between intellectual capital and firm performance. The theory emphasises on firms' resources and resources comprise the firms' assets from employee capabilities, procedures to financial position, data and knowledge. Barney (1991) demonstrated resources to three categories: physical capital which includes innovation, facilities, site and availability of raw materials; human capital in employees' knowledge, skills development, decision making, intellectual ability, connections and personal knowledge; and organisational capital resources in the form of formal reporting structure, formal and informal planning, control and coordination systems, and informal relationships. The resource-based theory seeks to explain how firms can adequately build and implement crucial resources to sustain competitive advantage. Barney et al. (2001) simplified the critical resource characteristics and capabilities, leading to sustained competitive advantage to four which are valuable, rare, inimitable, and non-substitutable. Therefore, our models test the effectivity of resource-based theory using listed SMEs in Malaysia as a research setting.

\section{Definition of Intellectual Capital}

In the literature, intellectual capital is viewed from many different dimensions, resulting in no single definition. However, most scholars agree the main components of intellectual capital are human capital, structural capital and relational capital (Ting, Ren, Chen and Kweh, 2020). Human capital is characterized as the mixed of abilities, experience, creativity and the capability of employees (Bontis, 2001). Firms need specific human capital characteristics to be able to compete and adapt to the rapidly changing business environment. Employees which represent human capital of the firm need to be innovative, talented, professional, possess appropriate skills in discharging their duties and responsibilities, contributing to novel innovations and expertise. In addition, reliable and skilled employees will challenge prevailing norms in firms with intention to offer improvement (Tushman \& Anderson, 1986; Snell and Dean, 1992). Further, savvy employees with highly problem-solving skills are vital in delivering effective decisions as well as employees with ability to collect relevant data, expertise and experience, they can enhance 
interpersonal efficiency and effectiveness. Thus, minimize errors in decision-making and result in greater productivity and firm performance (Hsu \& Wang 2012). Employees require resources to make the best use of their knowledge. This part presents intellectual capital's second major elements, known as structural capital. It is the company's investment in non-human factor of intangible assets. A firm requires structural support, providing its employees with resources and networks, and promoting their duties (Nawaz \& Haniffa, 2017). Scholars conclude structural capital forms the framework for all other intellectual capital components and tangible assets to be converted into outputs (Ferenhof, Durst, Bialecki, \& Selig, 2015). Apart from human capital, structural capital is also part of the firms's knowledge (Ting \& Lean, 2009). Structural capital is the elements of intellectual capital that remain with the company even without other intellectual capital elements (Carson, Ranzijn, Winefield, \& Marsden, 2004). Structural capital is collated in various ways, including tangible and intangible components. It is the firm's combined investment in its hardware, database or charters, process manuals, procedures, cultures, and intellectual property (Phusavat, Comepa, Sitko-Lutek, \& Ooi, 2011; Ramezan \& Farahani, 2015; Low, Samkin, \& Li, 2015). Structural capital plays a significant role in improving firms' performance, assisting firms to leverage their human resources, and businesses are now focused on building structural capital. Human capital integrates with structural capital, becomes the foundation for relational capital, enhancing customer loyalty to firms' products. The mix of structural capital and relational capital significantly affects human capital performance (Agostini, Nosella, \& Filippini, 2017). Relational capital represents the value of relationship with stakeholders. It is the knowledge embedded in the identification, development and maintenance of external relationship. Examples of the value are brand loyalty, market image, commercial power and reputation (Bontis, 1998; Stewart, 1997). Meanwhile, Sydler, Haefliger \& Pruksa (2014) describe relational capital as relationships with interest groups such as sponsors, external stakeholders, communication with suppliers and business people, and consumer relationships. Consequently, relational capital increases the productivity and the wealth of knowledge exchanged between business associates (Chen, Liu, Chu, \& Hsiao, 2014).

Unlike physical capital, the task of measuring intellectual capital in the annual reports is not specifically governed by the accounting standards resulting in numerous measurement models being proposed and introduced by scholars of intellectual capital (Nimtrakoon, 2015). However, Value Added Intellectual Coefficient (VAIC) model by Pulic (1998) has been used repetitively in the literature of intellectual capital, therefore it has been robustly tested (Joshi, Cahill, Sidhu and Kansal, 2013). In spite of the numerous advantages offered by VAIC model (e.g. objectivity, enhances comparability), this model is not without limitation. The model does not include measurement of relational capital, therefore this study will adopt the modified version called Modified Value Added Intellectual Coefficient (MVAIC) model which incorporates relational capital (Ulum, Ghozali \& Purwanto, 2014; Nimtrakoon, 2015). This model is discussed in Section 3.2 under subsection independent variables.

\section{Intellectual Capital and firm performance}

In attempts to understand the impact of intellectual capital on firm performance, the extant intellectual capital literature has covered a wide range of industry particularly knowledge- 
intensive industries such as banking (e.g. Al-Musali and Ku Ismail, 2016; Kehelwalatenna, 2016; Irsyahma \& Nikmah, 2017; Ozkan et al., 2017; Tran and Vo, 2018; Ousama, Hammami \& Abdul Karim, 2019), finance (e.g. Nawaz et al., 2017), information technology (e.g. Dzenopoljac, Janosevic \& Bontis, 2016), pharmaceutical (e.g. Chowdhury et al., 2019). Meanwhile, other industries example hotels (e.g. Sardo, Serrasqueiro \& Alves, 2018), textile (e.g. Chowdhury et al., 2018; Xu and Wang, 2019) have also been investigated.

It is observed from the literature review undertaken, most studies have proved that intellectual capital has a positive and significant impact on firm performance in the current competitive environment (e.g. Ozkan et al., 2017; Tran and Vo, 2018; Ousama et al., 2019; Xu and Wang, 2019). However, there are some studies that show little or no relationship (e.g. Dzenopoljac et al., 2016; Kehelwalatenna, 2016; Ting et al., 2020) suggesting that the empirical findings are still inconclusive. Scholars attributed the inconclusiveness of the empirical findings to countries differences, industries differences, business characteristic differences and unclear measurements, making the nature of the relationship between intellectual capital and firm performance not affirmative, thus creating a need for further studies (Xu and Li, 2019; Soewarno and Tjahjadi, 2020).

The above enumerated studies examined both the aggregate effect and the separate effect of intellectual capital on firm performance using either VAIC, MVAIC or A-VAIC models to measure intellectual capital efficiency. Apart from investigating the influence of intellectual capital on firm performance, prior studies also focused on the impact of intellectual capital components on firm performance. Further, the empirical findings reported a variation on the value creation capability of the components of intellectual capital and their effect on firm performance. Scholars claim value creation capability is largely contributed by human capital (e.g. Nimtrakoon, 2015; Dzenopoljac et al., 2016; Nawaz et al., 2017; Ozkan et al., 2017), while some reported structural capital has a significant influence on business performance (e.g. Vishnu and Gupta, 2014; Tiwari and Vidyarthi, 2018). Meanwhile, the findings of Scafarto, Ricci \& Scafarto (2016) documented positive contribution of relational capital towards firms' performance.

In addition, other studies revealed that human capital may affect firm performance indirectly through its positive impact on structural capital, relational capital and capital employed (e.g. Scafarto et al., 2016; Sardo et al., 2018; Tiwari et al., 2018; Tiwari, 2020). Scafarto et al. (2016) argue human capital, structural capital, relational capital on its own is not sufficient to deliver superior performance but it needs interaction with other components of intellectual capital so that the firm can leverage on its overall intangible value. For instance, human capital is required to establish structural capital, representing the knowledge of the firm, and together human capital and structural capital are required to build relational capital with the environment (Inkinen, 2015). Also, scholars such as Gonzalez-Loureiro and Dorrego (2012); Leitner (2011); Huang and Hsueh (2007); Hsu and Fang (2009) argue that firms' cumulative growth lie with the firms' ability to transform employees' knowledge into organizational knowledge resulting in higher probability of being innovative. In addition, the combined effect of human capital and relational capital improves the organisational learning capability and enhances new product 
development capabilities. Many research papers have provided evidence that human capital supports structural capital, relational capital, which in turn have a direct impact on firm performance (e.g. Huang and Hsueh, 2007; Hsu and Fang, 2009; Leitner; 2011; Gonzalez-Loureiro and Dorrego, 2012; Scafarto et al., 2016; Sardo et al., 2018; Tiwari et al., 2018; Tiwari, 2020). Therefore, this study attempts to make a contribution by measuring the moderating role of human capital in the relationship between intellectual capital and firm performance.

\section{Hypotheses Development}

To measure the nexus between intellectual capital using MVAIC model and profitability of listed SMEs in Malaysia, this study presents three testable research hypotheses.

First, it is hypothesised that the intellectual capital of listed SMEs in Malaysia is significant and positively associated to their profitability as asserted by resource-based theory. Several studies have reported the evidence of significant and positive relationship between intellectual capital and profitability (e.g. Vishnu et al., 2014; Nimtrakoon, 2015; Dzenopoljac et al., 2016; Scafarto et al., 2016; Nawaz et al., 2017; Ozkan et al., 2017; Tiwari et al., 2018; Xu et al., 2019; Tiwari, 2020). Thus, the first hypothesis is as follows:

H1 MVAIC significant and positively influences profitability of Listed SMEs in Malaysia. Intellectual capital measured using MVAIC model, is made up of human capital efficiency (HCE), structural capital efficiency (SCE), relational capital efficiency (RCE) and capital employed efficiency (CEE). As such, if intellectual capital is expected to significant and positively influence profitability, it is likely that its components will also significant and positively influence firm performance. A number of prior studies have provided evidence of such a relationship (e.g. Vishnu et al., 2014; Nimtrakoon, 2015; Dzenopoljac et al., 2016; Scafarto et al., 2016; Nawaz et al., 2017; Ozkan et al., 2017; Tiwari et al., 2018; Xu et al., 2019; Tiwari, 2020).Thus the second hypothesis is as follows:

$\mathrm{H} 2 \mathrm{a} \quad \mathrm{HCE}$ significant and positively influences profitability of Listed SMEs in Malaysia.

$\mathrm{H} 2 \mathrm{~b} \quad \mathrm{SCE}$ significant and positively influences profitability of Listed SMEs in Malaysia.

$\mathrm{H} 2 \mathrm{C} \quad$ RCE significant and positively influences profitability of Listed SMEs in Malaysia.

$\mathrm{H} 2 \mathrm{~d} \quad \mathrm{CEE}$ significant and positively influences profitability of Listed SMEs in Malaysia.

The value of intellectual capital is embedded in the interaction between its components. Intellectual capital does not work in isolation but rather complement each other, therefore the interaction impact positively the profitability of listed SMEs in Malaysia (e.g. Sardo et al., 2018: Tiwari et al., 2018; Tiwari, 2020). Thus, the third hypothesis is formulated as follows:

H3a HCE*SCE significant and positively influences profitability of Listed SMEs in Malaysia. $\mathrm{H} 3 \mathrm{~b} \quad \mathrm{HCE} * \mathrm{RCE}$ significant and positively influences profitability of Listed SMEs in Malaysia. $\mathrm{H} 3 \mathrm{C} \quad \mathrm{HCE}^{*} \mathrm{CEE}$ significant and positively influences profitability of Listed SMEs in Malaysia.

Further, to test the hypotheses of the study the following regression models are formulated: 
Vol. 11, No. 1, 2021, E-ISSN: 2225-8329 @ 2021 HRMARS

Model 1: $\quad \operatorname{ROA}_{i t}=\beta_{0}+\beta_{1}$ MVAIC $_{i t}+\beta_{2}$ Size $_{i t}+\beta_{3} \operatorname{Lev}_{i t}+\varepsilon_{i t}$

Model 2: $\quad R O A_{i t}=\beta_{0}+\beta_{1} \mathrm{HCE}_{i t}+\beta_{2} \mathrm{SCE}_{i \mathrm{t}}+\beta_{3} \mathrm{RCE}_{i \mathrm{t}}+\beta_{4} \mathrm{CEE}_{i \mathrm{t}}+\beta_{5}$ Size $_{i \mathrm{t}}+\beta_{6}$ Lev $_{i \mathrm{t}}+\varepsilon_{i \mathrm{t}}$

Model 3: $\quad R O A_{i t}=\beta_{0}+\beta_{1} \mathrm{HCE}_{i \mathrm{t}}+\beta_{2} \mathrm{SCE}_{i \mathrm{t}}+\beta_{3} \mathrm{RCE}_{i \mathrm{t}}+\beta_{4} \mathrm{CEE}_{i \mathrm{t}}+\beta_{5} \mathrm{HCE}_{i \mathrm{t}} \times \mathrm{SCE}_{i \mathrm{t}}+\beta_{6} \mathrm{HCE}_{i \mathrm{t}} \times \mathrm{RCE}_{i \mathrm{t}}$ $+\beta_{7} \mathrm{HCE}_{i \mathrm{t}} \times \mathrm{CEE}_{\mathrm{it}}+\beta_{8}$ Size $_{i \mathrm{t}}+\beta_{9} \operatorname{Lev}_{\mathrm{it}}+\varepsilon_{\text {it }}$

Here, $i$ denotes the cross-sectional dimension, $t$ represents the time-series dimension, $\beta_{0}$ is constant over time and specific to an individual firm $i . \beta_{1} \ldots . . . \beta_{9}$, are the coefficients of explanatory variable and $\varepsilon$ is an error term.

\section{Data and Methodology \\ Data}

Acknowledging the importance of SME towards economic growth, in July 2017 Bursa Malaysia Securities Berhad launched Leading Entrepreneur Accelerator Platform Market or LEAP market, providing SMEs with a platform for access to the Malaysian capital markets. The LEAP Market is a medium for SMEs to raise fund while failing to meet the listing requirements on the Main Market and the ACE market. SMEs with either cumulative net assets exceeding RM10 million, investors with net personal assets exceed RM3 million or gross annual income exceeds RM300,000, may enter the LEAP market. SMEs frequently strive to collect finances to meet their capital requirements and are mainly dependent on financial institutions to serve the theie funding needs. Financial firms account for around 96 per cent of overall funding for SMEs. The stock market, however, still accounts for less than 4 per cent of SME finance. The Bursa Malaysia predicts that the LEAP Market could address over-dependence on financial institutions and allow SMEs access to the capital market. The study uses panel data on 26 SMEs drawn from LEAP market for the period 2017-2019. The data are collected from the firms' official websites.

\section{Measurements of Variables}

This section presents the definition and measurement of all variables used in this research.

Dependent Variables: In the literature of intellectual capital, scholars often relate them to firm performance. Firm performance includes profitability, productivity, earnings, growth and market value (Latif et al., 2012; Smriti and Das, 2018). Indicators such as asset turnover ratio (ATO) a proxy for productivity, market to book value ratio, price to book value and Tobin's $Q$ proxy for market value, return on asset (ROA) and return on equity (ROE) proxy for profitability had been used in the previous study to measure firm performance. Following the research of Dzenopoljac et al. (2016) and Soewarno et al. (2020), this study adopts profitability (ROA) to measure firm performance. ROA is used to measure profitability because it has been used repetitively in the literature of intellectual capital, therefore, it has been robustly tested, and it increases the explanatory power of the regression models (Tiwari et al., 2018). This study uses Return on Asset (ROA) as an indicator of how profitable a firm is relative to its total assets which are net income divided by total assets. The equation: $R O A=$ Net Income $/$ Total Assets

Control Variables: In this study, two control variables are included into the regression models. The inclusion of the control variables is to minimise their effects as the objective of the study is 
INTERNATIONAL JOURNAL OF ACADEMIC RESEARCH IN ACCOUNTING, FINANCE AND MANAGEMENT SCIENCES

Vol. 11, No. 1, 2021, E-ISSN: 2225-8329 @ 2021 HRMARS

purely to measure the relationship between intellectual capital and firm performance (Sardo et al., 2018; Tiwari et al., 2018; Saewarno et al., 2020). The equations: Firm size = The natural logarithm of total assets and Leverage = Total Debt $/$ Total Assets.

Independent Variables: Intellectual capital is measured using Modified Value-Added Intellectual Coefficient or MVAIC model (e.g. Nimtrakoon, 2015; Tiwari et al., 2018; Xu et al., 2019). MVAIC is the sum of Human Capital Efficiency (HCE), Structural Capital Efficiency (SCE), Relational Capital Efficiency (RCE) and Capital Employed Efficiency (CEE).This model is an extension of VAIC model by Pulic (1998). The model adopts VAIC assumption that both, physical capital and intellectual capital is a function of production. The physical capital is represented by CEE and the intellectual capital is represented by the sum of HCE, SCE and RCE.

As a rule of thumb, the higher the value of MVAIC, the higher the value creation capability of the firm and mathematically computed as: $M V A I C=H C E+S C E+R C E+C E E$. To compute efficiency scores using MVAIC model; first, to establish the Value Added (VA) using the equation: $V A=O P$ $+E C+D+A$, where $\mathrm{OP}$ is operating profit, $\mathrm{EC}$ is employee costs, $\mathrm{D}$ is depreciation, $\mathrm{A}$ is amortisation. Second, to compute $H C E=V A / H C$, human capital $(H C)$ represents the investment made by the firm on its employees. It includes salary, wages and all incentives paid to employees. This ratio gives the contribution made by every unit of money invested in human capital to the value-added in the firm. In other words, HCE is an indicator of value added by the human resources employed by the business. Third, to compute SCE $=V A-H C / V A$, SCE indicates the proportion of total VA accounted by structural capital. SCE shows how much of the firm's value creation is generated by the structural capital. Fourth, $R C E=R C / V A$, relational capital $(\mathrm{RC})$ is the marketing cost of firms. This ratio gives the contribution made by every unit of relational capital to the value-added in the firm. Fifth, $C E E=V A / C E$, capital employed (CE) represents the tangible assets of the firm. CEE is a measure of physical capital. This ratio gives the contribution made by every unit of physical capital to the value-added in the firm.

Moderating Variable: This study examines the moderating effect of HCE on other components of MVAIC namely SCE, RCE and CEE. The formula for computing HCE is as follows: The equation: $H C E=V A / H C$.

\section{Empirical Findings \\ Descriptive Analysis}

Table 1 presents the descriptive analysis of the variables. The ROA ranges from -0.4525 to 0.4809 , with a mean value of 0.0739 and a standard deviation of 0.1251 . The small standard deviation shows that values are not widely dispersed and the low mean value suggests SMEs are struggling in making profit. The mean value of MVAIC is 3.0490, revealing that SMEs created RM3.0490 for every RM1 invested. The small standard deviation of 2.1333 shows that MVAIC is not widely dispersed across firms and it ranges from -0.4128 to 8.7579. Of the four components of MVAIC, HCE has the highest mean value of 2.1910, which indicates for every RM1 invested in human capital the value created is RM2.1910, the standard deviation is 1.7999 and the values ranging from -1.7355 to 7.5658 . It implies SMEs are generally more effective in generating value from 
their human capital compared to structural capital, relational capital and physical capital. The mean value of SCE is $0.5103, \mathrm{RCE}$ is 0.0975, CEE is 0.2501 , indicating that for every RM1 invested, firms created RM0.5103 from their structural capital, RM0.0975 from their relational capital and RM0.2501 from their physical capital. The standard deviation is 0.6549 for SCE, 0.2387 for RCE and 0.2073 for CEE, the low values show a consistency of the treatment in structural capital, relational capital and physical capital across firms. Firm size is measured as the natural logarithm of total assets at year end and the mean value is 6.2041. The standard deviation of total asset assets of 2.8126 is relatively high, suggesting there are significant variations in size among firms. The mean value of leverage is 0.3485 , indicating that $34.85 \%$ of firms' assets and operations are financed by debt. The low standard deviation of 0.2074 indicating high consistency across firms in their financing pattern.

Table 1: Descriptive Analysis

\begin{tabular}{|l|c|c|c|c|}
\hline \multicolumn{1}{|c|}{ Variables } & Mean & Std. Dev & Minimum & Maximum \\
\hline HCE & 2.1910 & 1.7999 & -1.7355 & 7.5658 \\
\hline SCE & 0.5103 & 0.6549 & -1.1534 & 5.2854 \\
\hline RCE & 0.0975 & 0.2387 & 0 & 1.1672 \\
\hline CEE & 0.2501 & 0.2073 & -0.2535 & 0.9755 \\
\hline MVAIC & 3.0490 & 2.1333 & -0.4128 & 8.7579 \\
\hline ROA & 0.0739 & 0.1251 & -0.4525 & 0.4809 \\
\hline FIRM SIZE & 6.2041 & 2.8126 & 0 & 8.0029 \\
\hline LEVERAGE & 0.3485 & 0.2074 & 0 & 0.7362 \\
\hline
\end{tabular}

\section{Correlation Analysis}

The Pearson's correlation analysis in table 2 shows a statistically significant positive correlation between ROA and MVAIC, HCE and CEE. SCE has a negative relationship with ROA, meanwhile RCE is found to have positive but insignificant association with ROA. Among the components of MVAIC, CEE has the highest correlation with ROA. Both, firm size and leverage have positive and significant relationship with ROA. The analysis indicate that the multicollinearity problem between direct effect variables is non-existent. Further, the results of variance inflation factor (VIF) are 2.24 for model 1 and 1.91 for model 2, confirming the data is free from multicollinearity issue. However, for interaction effect variables namely HCE and HCE*SCE (0.9796); RCE and $\mathrm{HCE}^{*} \mathrm{RCE}$ (0.9092), we noted that the correlation values are above 0.80 . According to Neter et al. (1985); El-Bannany (2002); Allison (2012) variables with interaction effect is expected to be highly correlated. As long as the direct effect variables are unaffected by the multicolinearity, this is not something to be concerned about (Tiwari, 2020). Thus, based on the above assertions, it is presumed that multicollinearity has no adverse consequences on model 3 of this study. 
INTERNATIONAL JOURNAL OF ACADEMIC RESEARCH IN ACCOUNTING, FINANCE AND MANAGEMENT SCIENCES

Vol. 11, No. 1, 2021, E-ISSN: 2225-8329 @ 2021 HRMARS

Table 2: Pearson Correlation Matrix

\begin{tabular}{|c|c|c|c|c|c|c|c|c|c|c|c|}
\hline $\begin{array}{c}\text { Variabl } \\
\text { es }\end{array}$ & HCE & SCE & RCE & CEE & MVAIC & ROA & SIZE & LEV & $\begin{array}{c}\mathrm{HCE}^{*} \mathrm{SC} \\
\mathrm{E}\end{array}$ & $\begin{array}{c}\mathrm{HCE}^{*} \mathrm{RC} \\
\mathrm{E}\end{array}$ & $\begin{array}{c}\mathrm{HCE}{ }^{*} \mathrm{CE} \\
\mathrm{E}\end{array}$ \\
\hline HCE & 1.0000 & & & & & & & & & & \\
\hline SCE & $0.2155^{*}$ & 1.0000 & & & & & & & & & \\
\hline $\mathrm{RCE}$ & -0.0633 & -0.1132 & 1.0000 & & & & & & & & \\
\hline CEE & $\begin{array}{c}0.4619 * \\
* *\end{array}$ & 0.0332 & 0.1106 & 1.0000 & & & & & & & \\
\hline MVAIC & $\begin{array}{c}0.6303^{*} \\
* *\end{array}$ & $\begin{array}{c}0.3425^{*} \\
*\end{array}$ & -0.0151 & $\begin{array}{c}0.2376^{*} \\
*\end{array}$ & 1.0000 & & & & & & \\
\hline ROA & $\begin{array}{c}0.6358 * \\
* *\end{array}$ & -0.1768 & 0.0210 & $\begin{array}{c}0.7882 * \\
* *\end{array}$ & $\begin{array}{c}0.3459 * \\
*\end{array}$ & 1.0000 & & & & & \\
\hline SIZE & $\begin{array}{c}0.5454^{*} \\
* *\end{array}$ & $\begin{array}{c}0.3201 * \\
*\end{array}$ & $0.2144^{*}$ & $\begin{array}{c}0.4932 * \\
* *\end{array}$ & $\begin{array}{c}0.4031 * \\
* *\end{array}$ & $0.2365^{*}$ & 1.0000 & & & & \\
\hline LEV & $\begin{array}{c}0.5488^{*} \\
* *\end{array}$ & $\begin{array}{c}0.4681 * \\
* *\end{array}$ & -0.0514 & $\begin{array}{c}0.4559 * \\
* *\end{array}$ & $\begin{array}{c}0.3981 * \\
* *\end{array}$ & $0.2344^{*}$ & $\begin{array}{c}0.7323^{*} \\
* *\end{array}$ & 1.0000 & & & \\
\hline $\begin{array}{c}\mathrm{HCE}^{*} \mathrm{SC} \\
\mathrm{E}\end{array}$ & $\begin{array}{c}0.9796 * \\
* *\end{array}$ & 0.1613 & -0.1145 & $\begin{array}{c}0.3784 * \\
* *\end{array}$ & $\begin{array}{c}0.6459 * \\
* *\end{array}$ & $\begin{array}{c}0.6393 * \\
* *\end{array}$ & $\begin{array}{c}0.3747^{*} \\
* *\end{array}$ & $\begin{array}{c}0.4315^{*} \\
* *\end{array}$ & 1.0000 & & \\
\hline $\begin{array}{c}\mathrm{HCE}^{*} \mathrm{RC} \\
\mathrm{E}\end{array}$ & 0.0515 & -0.0226 & $\begin{array}{c}0.9092 * \\
* *\end{array}$ & $0.2527^{*}$ & 0.0568 & $0.2201^{*}$ & $0.2247^{*}$ & 0.0010 & 0.0069 & 1.0000 & \\
\hline $\begin{array}{c}\mathrm{HCE}^{*} \mathrm{CE} \\
\mathrm{E}\end{array}$ & $\begin{array}{c}0.7813^{*} \\
* *\end{array}$ & $0.2149 *$ & -0.0109 & $\begin{array}{c}0.7218 * \\
* *\end{array}$ & $\begin{array}{c}0.4271 * \\
* *\end{array}$ & $\begin{array}{c}0.7477^{*} \\
* *\end{array}$ & $\begin{array}{c}0.3857^{*} \\
* *\end{array}$ & $\begin{array}{c}0.5226 * \\
* *\end{array}$ & $\begin{array}{c}0.7555^{*} \\
* *\end{array}$ & 0.1707 & 1.0000 \\
\hline
\end{tabular}


INTERNATIONAL JOURNAL OF ACADEMIC RESEARCH IN ACCOUNTING, FINANCE AND

MANAGEMENT SCIENCES

Vol. 11 , No. 1 2021, E-ISSN: 2225-8329 @ 2021 HRMARS

\section{Regression Analysis}

The overall fit of model 1 is examined through the $R^{2}$ of 0.3456 with the wald Chi-Sq of $48.7(p<0.000)$. It is indicated that 34.56 per cent variation in ROA is explained by the variables in model 1 and the model is statistically significant.The result of model 1 reveals that the impact of MVAIC on ROA is positive and significant. Thus, validated the resource-based view employed in the study. The findings of the study is broadly in line with the studies of Nimtrakoon, 2015; Tiwari et al., 2018; Wang et al., 2018; Xu et al., 2019; Saewarno et al., 2020. Thus, the findings support H1, confirming that firms with greater MVAIC tend to have higher profitability.

Concerning $\mathrm{H} 2$, the $\mathrm{R}^{2}$ of 0.8368 with F-statistical test of $79.73(p<0.000)$ indicate that model 2 ia capable of explaining about 83.68 per cent of the variation in the firms' ROA and the model is statistically significant. Measuring the impact of the four components of MVAIC on ROA, the findings from model 2 indicate that CEE has a positive and significant relationship with ROA, based on the coefficient value of 0.5267 suggesting the profitability of listed SMEs in Malaysia is primarily driven by CEE, implying the relevance of physical capital in today's dynamic, globalization, competitive and changing market setting. In addition, HCE is positive and significantly associated with ROA. With coefficient value of 0.0329 , it shows HCE marginally increases profitability. SCE has significant but negative relationship with ROA. While, RCE is proven to be statistically insignificant with ROA. The findings are in line with many prior studies that revealed insignificant association between RCE and ROA (e.g. Xu and Li, 2019; Nimtrakoon, 2015). The findings support H2a and H2d, but not H2b and H2c, confirming that firms with greater physical capital and human capital, but not structural capital and relational capital, tend to have higher profitability. The findings suggest that resource-based theory per se may not be sufficient in governing the relationship between intellectual capital and profitability. Recent intellectual capital literature has incorporated resource dependency and organizational learning theories to explain the exclusive nature of intellectual capital and its components in increasing firms' strategic management and profitability (e.g. Nadeem, Gan and Nguyen, 2017; Smriti and Das, 2018). These two theories provide views from external environment.

Regarding $\mathrm{H} 3$, the $\mathrm{R}^{2}$ of 0.8322 with F-statistical test of $86.38(\mathrm{p}<0.000)$ indicate that model 3 is capable of explaining about 83.22 per cent of the variation in the firms' ROA and the model is statistically significant. In model 3 when an interaction term is included, HCE*SCE is positive and significant with ROA, similar association is also noted for HCE*RCE and ROA. The results show that human capital efficiency moderates positively the effect of SCE and RCE on ROA. The results suggest that human capital provides the skill to build the firm knowledge base which enhances profitability. Further, the knowledge embedded with employees combined with efficient processes and functioning external networks is the most effective equation to achieve success for the firms (Inkinen, 2015). The findings corroborate with the study of Sardo et al. (2018); Tiwari (2020). However, negative association between $\mathrm{HCE}^{*} \mathrm{CEE}$ and ROA was revealed. The findings support $\mathrm{H} 3 \mathrm{a}$ and $\mathrm{H} 3 \mathrm{~b}$ but not $\mathrm{H} 3 \mathrm{c}$, confirming that human capital moderate positively the effect of structural capital and relational capital on profitability, but not physical capital. 
INTERNATIONAL JOURNAL OF ACADEMIC RESEARCH IN ACCOUNTING, FINANCE AND MANAGEMENT SCIENCES

Vol. 11, No. 1 2021, E-ISSN: 2225-8329 @ 2021 HRMARS

The regression results of the three models are presented in table 3.

Table 3: Regression Results

\begin{tabular}{|c|c|c|c|}
\hline Model & 1 & 2 & 3 \\
\hline Variables & ROA & ROA & ROA \\
\hline $\begin{array}{l}\text { Cons } \\
\text { t-value }\end{array}$ & $\begin{array}{c}0.0003 \\
(0.01)\end{array}$ & $\begin{array}{c}-0.0014 \\
(-0.13)\end{array}$ & $\begin{array}{c}-0.0057 \\
(-0.61)\end{array}$ \\
\hline $\begin{array}{l}\text { MVAIC } \\
t \text {-value }\end{array}$ & $\begin{array}{c}0.0449 * * * \\
(5.92)\end{array}$ & NA & NA \\
\hline $\begin{array}{l}\text { HCE } \\
\text { t-value }\end{array}$ & NA & $\begin{array}{c}0.0329 * * * \\
(6.60)\end{array}$ & $\begin{array}{c}-0.1211^{* *} \\
(-2.44)\end{array}$ \\
\hline $\begin{array}{l}\text { SCE } \\
\mathrm{t} \text {-value }\end{array}$ & NA & $\begin{array}{c}-0.0241^{* *} \\
(-2.25) \\
\end{array}$ & $\begin{array}{c}-0.0358^{* * *} \\
(-3.97) \\
\end{array}$ \\
\hline $\begin{array}{l}\text { RCE } \\
t \text {-value }\end{array}$ & NA & $\begin{array}{c}0.0620 \\
(1.19)\end{array}$ & $\begin{array}{c}-0.0542 \\
(-1.01)\end{array}$ \\
\hline $\begin{array}{l}\text { CEE } \\
\mathrm{t} \text {-value }\end{array}$ & NA & $\begin{array}{c}0.5267^{* * *} \\
(12.73) \\
\end{array}$ & $\begin{array}{c}0.5898^{* * *} \\
(12.49) \\
\end{array}$ \\
\hline $\begin{array}{l}\text { HCE*SCE } \\
\text { t-value }\end{array}$ & NA & NA & $\begin{array}{c}0.1548^{* * *} \\
(3.27)\end{array}$ \\
\hline $\begin{array}{l}\text { HCE*RCE } \\
\text { t-value }\end{array}$ & NA & NA & $\begin{array}{c}0.1077^{* * *} \\
(3.62)\end{array}$ \\
\hline $\begin{array}{l}\text { HCE*CEE } \\
\text { t-value }\end{array}$ & NA & NA & $\begin{array}{c}-0.0309^{*} \\
(-1.78)\end{array}$ \\
\hline $\begin{array}{l}\text { Size } \\
\text { t-value }\end{array}$ & $\begin{array}{c}-0.0070 \\
(-1.09)\end{array}$ & $\begin{array}{c}-0.0213^{* * *} \\
(-5.99)\end{array}$ & $\begin{array}{c}-0.0019 \\
(-0.27)\end{array}$ \\
\hline $\begin{array}{l}\text { Lev } \\
\text { t-value }\end{array}$ & $\begin{array}{c}-0.0563 \\
(-0.61)\end{array}$ & $\begin{array}{c}0.0291 \\
(0.53)\end{array}$ & $\begin{array}{l}0.0673 \\
(1.43)\end{array}$ \\
\hline $\mathrm{R}-\mathrm{Sq}$ & 0.3456 & 0.8368 & 0.8322 \\
\hline F-stat & - & 79.73 & 86.38 \\
\hline Sig F-stat & - & 0.0000 & 0.0000 \\
\hline Wald Chi-Sq & 48.70 & - & - \\
\hline$p$-value & 0.0000 & - & - \\
\hline
\end{tabular}

Notes: $* * *, * *, *$ indicate statistical significance at the 1,5 and 10 percent level respectively. The figures in the parentheses are the t-statistics. $\mathrm{N}$ is number of observation.

\section{Conclusion}

Based on 26 firms taken from the LEAP market of Bursa Malaysia for the period 2017-2019, this study seeks to understand the nexus between intellectual capital and profitability of SMEs in Malaysia while considering interaction effect of human capital. The MVAIC is used to measure the intellectual capital at Malaysian SMEs. The empirical findings of this study reveal a positive association between intellectual capital and profitability. Eventhough, intellectual capital is linked to profitability, but the coefficient value of 0.0499 is considerably low suggesting limited investment in intellectual capital. Thus, to enhance profitability, it is crucial for SMEs to focus on stimulating investments in intellectual 
INTERNATIONAL JOURNAL OF ACADEMIC RESEARCH IN ACCOUNTING, FINANCE AND MANAGEMENT SCIENCES

Vol. 11, No. 1 2021, E-ISSN: 2225-8329 ๔ 2021 HRMARS

capital and to seek favourable government policies (Tiwari, 2020). In addition, the empirical findings reveal two out of four components of MVAIC namely HCE and CEE are positive and significantly contributing to profitability. SCE is significant but negatively associated with profitability. While, RCE is proven to be statistically insignificant with profitability. However, another interesting results obtained from the estimation is that human capital efficiency moderates positively the effect of structural capital and relational capital on profitability. Thus, the empirical findings of the study may help to resolve the mixed findings in prior studies on the impact of intellectual capital components on profitability.

The findings of the study make several contributions. First, as the results imply, SMEs still operate based on physical capital, therefore management should focus on how to use and manage their physical resources effectively to achieve a higher level of profitability. Second, intellectual capital is positive and significantly associated with profitability of listed SMEs in Malaysia, as such improving and accumulating high levels of intellectual capital is encouraged for SMEs to achieve further success. Third, one component of intellectual capital namely HCE, contributes positive and significantly to the profitability of SMEs. Therefore, it is crucial to further strengthen the personnel structure and employee efficiency to improve future profitability. Although, SCE and RCE have not shown favourable effects, they are valuable assets that should not be neglected if SMEs wish to maintain competitiveness in the market. Further, the positive interaction proves that human capital provides the necessary skill and competency to build the firm knowledge base which enhances profitability. The combined knowledge of employees, efficient processes and functioning external networks is the most effective mechanism to achieve success for SMEs. Fourth, the findings suggest that resource-based theory per se may not be sufficient in governing the relationship between intellectual capital and profitability. Intellectual capital needs to be viewed from external environment as elaborated by resource dependency and organizational learning theories in increasing firms' strategic management and profitability.

This study examines the impact of intellectual capital on profitability. Future research may consider examining and exploring the relationship between intellectual capital and other fundamental aspects of firms such as capital structure, corporate governance, corporate value, productivity and corporate social responsibility. Further, the study examines one country and one industry, therefore, limit the generalisation of findings.

\section{References}

Agostini, L., Nosella, A., \& Filippini, R. (2017). Does intellectual capital allow improving innovation performance? A quantitative analysis in the SME context. Journal of Intellectual Capital, 18(2), 400-418.

Ali, K. A. (2014). The impact of financial leverage on firm performance: The case of non-financial firms in Kenya. (unpublished master thesis). University of Nairobi.

Allison, P. (2012). When can you safely ignore multicollinearity. Statistical Horizons, 5(1), available at: https://statisticalhorizons.com/multicollinearity

Al-Musali, M., \& Ku Ismail, K. N. I. (2016). Cross-country comparison of intellectual capital performance and its impact on financial performance of commercial banks in GCC countries. International Journal of Islamic and Middle Eastern Finance and Management, 9(4), 512-531. 
INTERNATIONAL JOURNAL OF ACADEMIC RESEARCH IN ACCOUNTING, FINANCE AND

MANAGEMENT SCIENCES

Vol. 11 , No. 1 2021, E-ISSN: 2225-8329 @ 2021 HRMARS

Barney, J. (1991). Firm Resources and Sustained Competitive Advantage. Journal of Management, 17(1), 99.

Bontis, N. (1998). Intellectual capital: an exploratory study that develops measures and models. Management decision, 36(2), 63-76.

Bontis, N. (2001). Assessing knowledge assets: a review of the models used to measure intellectual capital. International journal of management reviews, 3(1), 41-60.

Carson, E., Ranzijn, R., Winefield, A., \& Marsden, H. (2004). Intellectual capital: Mapping employee and work group attributes. Journal of Intellectual Capital, 5(3), 443-463.

Chen, C.-J., Liu, T.-C., Chu, M.-A., \& Hsiao, Y.-C. (2014). Intellectual capital and new product development. Journal of Engineering and Technology Management, 33, 154-173.

Dženopoljac, V., Janoševic, S., \& Bontis, N. (2016). Intellectual capital and financial performance in the Serbian ICT industry. Journal of Intellectual Capital, 17(2), 373-396.

Chowdhury, L. A. M., Rana, T., Akter, M., \& Hoque, M. (2018). Impact of intellectual capital on financial performance: evidence from the Bangladeshi textile sector. Journal of Accounting \& Organizational Change, 14(4), 429-454.

Chowdhury, L. A. M., Rana, T., \& Azim, M. I. (2019). Intellectual capital efficiency and organisational performance. Journal of Intellectual Capital, 20(6), 784-806.

El-Bannany, M. (2002). Investment in information technology systems and other determinants of bank performance in the UK and Egypt. Unpublished PHDthesis, Liverpool John Moores University, Liverpool.

Ferenhof, H., Durst, S., Bialecki, M., \& Selig, P. (2015). Intellectual capital dimensions: state of the art in 2014. Journal of Intellectual Capital, 16(1), 58-100.

Gonzalez-Loureiro, M. \& Dorrego, P.F. (2012). Intellectual capital and system of innovation:what really matters at innovative SMEs, Intangible Capital, 8(2), 239-274.

Huang, C.-F., \& Hsueh, S.-L. (2007). A study on the relationship between intellectual capital and business performance in the engineering consulting industry: a path analysis. Journal of Civil Engineerng and Management, 13(4), 265-271.

Hsu, Y.-H., \& Fang, W. (2009). Intellectual capital and new product development performance: the mediating role of organizational learning capability. Technological Forecasting and Social Change, 76(5), 664-677.

Hsu, L.-C., \& Wang, C.-H. (2012). Clarifying the effect of intellectual capital on performance: the mediating role of dynamic capability, 23(2). British Journal of Management, 179-205.

Inkinen, H. (2015). Review of empirical research on intellectual capital and firm performance. Journal of Intellectual Capital, 16(3), 518-565.

Irsyahma, A., \& Nikmah, N. (2017). Intellectual Capital, Firm Value, and Financial Performance. AFEBI Accounting Review, 1(1), 29-43.

Joshi, M., Cahill, D., Sidhu, J., \& Kansal, M. (2013). Intellectual capital and financial performance: an evaluation of the Australian financial sector. Journal of intellectual capital, 14(2), 264-285.

Kehelwalatenna, S. (2016). Intellectual capital performance during financial crises. Measuring Business Excellence, 20 (3), 55-78.

Latif, M., Malik, M. S., and Aslam, S. (2012). Intellectual capital efficiency and corporate performance in developing countries: A comparison between Islamic and conventional banks of Pakistan. Interdisciplinary Journal of Contemporary Research in Business, 4(1), 405-420. 
INTERNATIONAL JOURNAL OF ACADEMIC RESEARCH IN ACCOUNTING, FINANCE AND

MANAGEMENT SCIENCES

Vol. 11, No. 1 2021, E-ISSN: $2225-8329$ @ 2021 HRMARS

Leither, K.-H. (2011). The effect of intellectual capital on product innovativeness in SMEs. International Journal of Technology Management. 53(1), 1-18.

Low, M., Samkin, G., \& Li, Y. (2015). Voluntary reporting of intellectual capital. Journal of Intellectual Capital, 16(4), 779-808.

Muda, S., and Rahman M.R.C.A. (2018). Intellectual Capital and Performance: a Study on Malaysian SMEs. In Proceedings of 8th International Economics and Business Management Conference, the European Proceedings of Social and Behavioural Sciences, pp. 382-391.

Nadeem, M., Gan, C., \& Nguyen, C. (2017). Does intellectual capital efficiency improve firm performance in BRICS economies? A dynamic panel estimation. Measuring Business Excellence, 21(1), 65-85.

Nawaz, T., \& Haniffa, R. (2017). Determinants of financial performance of Islamic banks: an intellectual capital perspective. Journal of Islamic Accounting and Business Research, 8(2), 130-142.

Neter, J., Wasserman, W., \& Kutner, M. H. (1985). Multicollinearity, influential observations, and other topics in regression analysis-II. In Applied statistical linear models (Vol. 101, pp. 390393). Richard D. Irwin, Inc. Homewood.

Ngah, R., and Ibrahim, A.R. (2009). The relationship of intellectual capital, innovation and organizational performance: a preliminary study in Malaysian SMEs. International Journal of Management Innovation System, 1(1),1-13.

Nimtrakoon, S. (2015). The relationship between intellectual capital, firms' market value and financial performance. Journal of Intellectual Capital, 16(3), 587-618.

Ousama, A., Hammami, H., \& Abdul karim, M. (2019). The association between intellectual capital and financial performance in the Islamic banking industry. International Journal of Islamic and Middle Eastern Finance and Management, 13(1), 75-93.

Ozkan, N., Cakan, S., \& Kayacan, M. (2017). Intellectual capital and financial performance: A study of the Turkish Banking Sector. Borsa Istanbul Review, 17(3), 190-198.

Phusavat, K., Comepa, N., Sitko-Lutek, A., \& Ooi, K.-B. (2011). Interrelationships between intellectual capital and performance: Empirical examination. Industrial Management \& Data Systems, 111(6), 810-829.

Pulic, A. (1998). Measuring the Performance of Intellectual Potential in Knowledge Economy. (presented in 1998 at the $2^{\text {nd }}$ McMaster World Congress on Measuring and Managing Intellectual Capital by the Austrian Team for Intellectual Potential).

Retrieved from http://www.measuringip.at/Opapers/Pulic/Vaictxt.vaictxt.html

Ramezan, M., \& Farahani, M. (2015). Measurement of intellectual capital in the academic research and development units. WALIA journal 31(S1), 206-210.

Sardo, F., Serrasqueiro, Z., \& Alves, H. (2018). On the relationship between intellectual capital and financial performance: A panel data analysis on SME hotels. International Journal of Hospitality Management, 75, 67-74.

Scafarto, V., Ricci, F., \& Scafarto, F. (2016). Intellectual capital and firm performance in the global agribusiness industry. Journal of Intellectual Capital, 17(3), 530-552.

Shaari, J. A. N., Isa, A. H., and Khalique, M. (2018). Impact of Intellectual Capital on Organizational Performance of ICT SMEs in Penang, Malaysia. Market Forces, 13(2).

SMECorp Malaysia. (2019). SMEs Performance in 2018. Retrieved 30 September 2020 from http://www. Smecorp.gov.my. 
INTERNATIONAL JOURNAL OF ACADEMIC RESEARCH IN ACCOUNTING, FINANCE AND

MANAGEMENT SCIENCES

Vol. 11 , No. 1 2021, E-ISSN: 2225-8329 @ 2021 HRMARS

Smriti, N., \& Das, N. (2018). The impact of intellectual capital on firm performance: a study of Indian firms listed in COSPI. Journal of Intellectual Capital, 19(5), 935-964.

Snell, S., \& Dean, J. (1992). Integrated manufacturing and human resource management: A human capital perspective. Academy of Management journal, 35(3), 467-504.

Soewarno, N., and Tjahjadi, B. (2020). Measures that matter: an empirical investigation of intellectual capital and financial performance of banking firms in Indonesia. Journal of Intellectual Capital, 21(6), 1085-1106.

Stewart, G. (1997). Supply-chain operations reference model (SCOR): the first cross-industry framework for integrated supply-chain management. Logistics Information Management, 10(2), 62-67.

Sydler, R., Haefliger, S., \& Pruksa, R. (2014). Measuring intellectual capital with financial figures: Can we predict firm profitability? European Management Journal, 32(2), 244-259.

Ting, I., Ren, C., Chen, F.-C., \& Kweh, Q. (2020). Interpreting the dynamic performance effect of intellectual capital through a value-added-based perspective. Journal of Intellectual Capital, 21(3), 381-401.

Ting, I., \& Lean, H. (2009). Intellectual capital performance of financial institutions in Malaysia. Journal of Intellectual Capital, 10(4), 588-599.

Tiwari, R., \& Vidyarthi, H. (2018). Intellectual capital and corporate performance: a case of Indian banks. Journal of Accounting in Emerging, 8(1), 84-105.

Tiwari, R. (2020). Nexus between intellectual capital and profitability with interaction effects: Panel data evidence from the Indian healthcare industry. Journal of Intellectual Capital. DOI 10.1108/JIC-05-2020-0137.

Tran, D., \& Vo, D. (2018). Should bankers be concerned with Intellectual capital? A study of the Thai banking sector. Journal of Intellectual Capital, 19(5), 897-914.

Tushman, M., \& Anderson, P. (1986). Technological discontinuities and organizational environments. Administrative science quarterly, 439-465.

Ulum, I., Ghozali, I., \& Purwanto, A. (2014). Intellectual capital performance of Indonesian banking sector: a modified VAIC (M-VAIC) perspective. International Journal of Finance \& Accounting, 6(2), 103-123.

Vishnu, S., \& Gupta, V. (2014). Intellectual capital and performance of pharmaceutical firms in India. Journal of Intellectual Capital, 15(1), 83-99.

$\mathrm{Xu}$, J., \& Li, J. (2019). The impact of intellectual capital on SMEs' performance in China. Journal of Intellectual Capital, 20(4), 488-509.

Xu, J., \& Wang, B. (2019). Intellectual capital performance of the textile industry in emerging markets: A comparison with China and South Korea. Sustainability, 11(8), 2354.

Zin, S. M., and Ashari, E. H. M. E. H. (2020). How Do Intellectual Capital and Islamic Work Ethics Affect SME Business Performance? Jurnal Intelek, 15(1), 77-88. 